\title{
EFFECT OF THYROID ACTIVITY UPON DELAYED IMPLANTATION OF BLASTOCYSTS IN THE RAT
}

\author{
J. P. HOLLAND, J. M. DORSEY, JR, N. N. HARRIS AND F. L. JOHNSON \\ Department of Zoology, Howard University, Washington, D.C., U.S.A.
}

(Received 9th May 1966, revised 9th August 1966)

\begin{abstract}
Summary. The effects of L-thyroxine and of surgical thyroidectomy upon the survival of blastocysts have been studied in 200 albino rats. These rats were ovariectomized on the 3rd day of pregnancy, and maintained on progesterone in order to delay implantation. Delay of implantation was confirmed by laparotomy on the 8th day of pregnancy. Subsequent implantation was accomplished by giving $1 \mu \mathrm{g}$ oestrone daily from the 9th day of pregnancy. At autopsy on the 14th day of pregnancy hyperthyroid rats and hypothyroid rats which had been maintained on daily injections of $2.0 \mathrm{mg}$ progesterone did not differ from their respective control groups in the number of surviving blastocysts. However, hyperthyroid rats which had been maintained on daily injections of $0.4 \mathrm{mg}$ progesterone possessed more implantation sites than controls. Similarly, the hypothyroid rats maintained on daily injections of $0.3 \mathrm{mg}$ progesterone had fewer implantation sites than controls. The experiments suggest that the level of hyperthyroidism tested is beneficial to the maintenance of implantation of delayed blastocysts when low amounts of progesterone are available, while hypothyroidism tends to be detrimental to this process during low progesterone availability.
\end{abstract}

\section{INTRODUGTION}

Hypothyroidism has been reported to favour pregnancy (Johnson \& Meites, 1950; Wilson \& Chai, 1962), but it has also been said to be disadvantageous (Williams, Weinglass, Bissel \& Peters, 1944; Peterson, Webster, Rayner \& Young, 1952; Janes \& Bradbury, 1952); and without effect (Desaive, 1948; Krohn, 1951). The effects reported for hyperthyroidism are equally conflicting (Hoar, Goy \& Young, 1951; Peterson et al., 1952). Differences in species or types of animals used, in dosages of ovarian hormones and in extent of hypothyroidism or hyperthyroidism may have contributed to these discrepancies. Since thyroid hormone influences metabolic rate, changes in thyroid activity may be associated with differences in requirements for or use of ovarian hormones. Investigations of this possibility should be useful in the attempt to clarify the role of the thyroid in reproduction. The present study employs the technique of experimentally delayed implantation of blastocysts in rats (Cochrane \& Meyer, 1957; Mayer, 1963; Canivenc \& Laffarque, 1956; Nutting \& Meyer, 
1963). This technique allows the investigator to control implantation time and to control the levels of ovarian hormones available during early pregnancy.

\section{MATERIALS AND METHODS}

Two hundred Holtzman virgin female albino rats, between 90 and 120 days old, were maintained on Purina Laboratory chow and tap water in an animal room at $21^{\circ} \mathrm{C}$ with constant periods of light and darkness. Vaginal smears were taken daily, and receptive females were placed overnight in cages with adult male rats. Insemination was confirmed early on the following morning by the presence of spermatozoa in vaginal smears. This day was designated as Day 1 of pregnancy.

Implantation was delayed by the technique of Cochrane \& Meyer (1957). On Day 3 of pregnancy ovariectomies were performed through dorso-lateral incisions. All surgical procedures were performed under ether anaesthesia. Benzalkonium chloride was used for antisepsis. The ovaries were excised by ligating the mesovarium, opening the ovarian bursa and cutting the connecting ligament. Extreme care was taken to minimize injury of the oviducts. Beginning on Day 3 and extending to Day 8, the ovariectomized rats were given daily subcutaneous injections of progesterone in the dorsal region of the neck. Delay of implantation was confirmed on Day 8 by mid-ventral laparotomy. Hyperthyroidism was induced by daily injections of $48 \mu \mathrm{g} L$-thyroxine. Two groups of thyroxine-treated rats were tested: in one group, thyroxine injections were begun at least 10 days before insemination (early-hyperthyroid rats) while in the other group thyroxine injections were begun on the day of insemination (hyperthyroid rats). All injections of thyroxine were continued to Day 13. After insemination and ovariectomy the early-hyperthyroid, hyperthyroid and control rats were assigned to one of two daily doses of progesterone, namely, $2 \cdot 0$ or $0.4 \mathrm{mg}$.

Thyroidectomies were performed through a mid-ventral incision in the neck. All thyroidectomies occurred at least 5 weeks before the day of insemination. After insemination and ovariectomy the thyroidectomized rats and control rats were assigned to one of two daily doses of progesterone, namely, 2.0 or $0.3 \mathrm{mg}$.

All animals received $1 \mu \mathrm{g}$ oestrone daily from Day 9 to Day 13 . The progesterone and oestrone were administered in $0.2 \mathrm{ml}$ corn oil.

At autopsy on Day 14 the uterus of each rat was examined for implantation sites.

\section{RESULTS}

Hyperthyroidism

Table 1 summarizes the observations on hyperthyroid rats maintained on two levels of progesterone. Three rats in which implantation occurred before laparotomy were omitted from the record. Neither of the two hyperthyroid groups which received $2.0 \mathrm{mg}$ progesterone differed significantly from their control group in number of implantation sites. The means resemble those of 
Nutting \& Meyer (1963), who maintained rats on $2.0 \mathrm{mg}$ progesterone for a longer period (to Day 13).

Reduction of the progesterone dose from 2.0 to $0.4 \mathrm{mg}$ daily in control rats yielded a significant reduction in the number of implantation sites per rat. This agrees with findings reported by Nutting \& Meyer (1963) and by Meyer \& Nutting (1964). The early-hyperthyroid rats receiving $0.4 \mathrm{mg}$ progesterone daily had significantly more implantation sites per rat than the $0.4 \mathrm{mg}$ controls. The hyperthyroid rats receiving this low progesterone dose, however, did not show an increase in number of implantation sites.

In the controls, the proportion of animals without implantation sites increased when the progesterone dose was decreased. On the other hand, the

TABLE 1

THE EFFECT OF PROGESTERONE AND THYROXINE OR SURGIGAL THYROIDECTOMY UPON DELAYED IMPLANTATION OF BLASTOGYSTS IN OVARIECTOMIZED RATS

\begin{tabular}{|c|c|c|c|c|c|c|c|}
\hline & \multirow{2}{*}{$\begin{array}{c}\text { Daily } \\
\text { dose of } \\
\text { progesterone } \\
\text { (mg) }\end{array}$} & \multirow{2}{*}{$\begin{array}{l}\text { Daily dose of } \\
\text { thyroxine }(\mu g)\end{array}$} & \multirow{2}{*}{$\begin{array}{l}\text { No. } \\
\text { of } \\
\text { rats }\end{array}$} & \multicolumn{2}{|c|}{$\begin{array}{l}\text { Rats with no } \\
\text { implantation } \\
\text { sites }\end{array}$} & \multicolumn{2}{|c|}{ Sites at autopsy } \\
\hline & & & & No. & $\%$ & No. & $\begin{array}{c}\text { Mean } \pm \\
\text { standard error }\end{array}$ \\
\hline $\begin{array}{l}\text { Controls for } \\
\text { hyperthyroid rats }\end{array}$ & $\begin{array}{l}2 \cdot 0 \\
0 \cdot 4\end{array}$ & $\begin{array}{l}0 \\
0\end{array}$ & $\begin{array}{l}24 \\
23\end{array}$ & $\begin{array}{l}1 \\
7\end{array}$ & $\begin{array}{r}4 \\
30\end{array}$ & $\begin{array}{r}147 \\
90\end{array}$ & $\begin{array}{l}6.12 \pm 0.73 \\
3.91 \pm 0.78^{*}\end{array}$ \\
\hline Hyperthyroid rats & $\begin{array}{l}2 \cdot 0 \\
2 \cdot 0 \\
0 \cdot 4 \\
0 \cdot 4\end{array}$ & $\begin{array}{l}48 \\
48 \text { (early) } \dagger \\
48 \text { (early) } \dagger\end{array}$ & $\begin{array}{l}21 \\
21 \\
24 \\
25\end{array}$ & $\begin{array}{l}4 \\
2 \\
7 \\
1\end{array}$ & $\begin{array}{r}19 \\
9 \\
29 \\
4\end{array}$ & $\begin{array}{r}105 \\
141 \\
82 \\
150\end{array}$ & $\left\{\begin{array}{l}5.00 \pm 0.99 \\
6.70 \pm 1.06 \\
3.42 \pm 0.72 \\
6.00 \pm 0.64 * *\end{array}\right.$ \\
\hline $\begin{array}{l}\text { Control for } \\
\text { thyroidectomized rats }\end{array}$ & $\begin{array}{l}2 \cdot 0 \\
0 \cdot 3\end{array}$ & $\begin{array}{l}0 \\
0\end{array}$ & $\begin{array}{l}20 \\
16\end{array}$ & $\begin{array}{l}1 \\
6\end{array}$ & $\begin{array}{r}5 \\
38\end{array}$ & $\begin{array}{r}107 \\
48\end{array}$ & $\begin{array}{l}5 \cdot 3 \pm 0.65 \\
3 \cdot 0 \pm 0.77^{*}\end{array}$ \\
\hline $\begin{array}{l}\text { Thyroidectomized } \\
\text { rats }\end{array}$ & $\begin{array}{l}2 \cdot 0 \\
0 \cdot 3\end{array}$ & $\begin{array}{l}0 \\
0\end{array}$ & $\begin{array}{l}11 \\
15\end{array}$ & $\begin{array}{l}1 \\
8\end{array}$ & $\begin{array}{r}9 \\
53\end{array}$ & $\begin{array}{l}61 \\
24\end{array}$ & $\begin{array}{l}5 \cdot 1 \pm 1 \cdot 0 \\
1 \cdot 6 \pm 0.66\end{array}$ \\
\hline
\end{tabular}

All animals were laparotomized on Day 8 of pregnancy and all received $1 \mu \mathrm{g}$ oestrone daily from Day 9 to Day 13.

\footnotetext{
* Significantly different from $2.0 \mathrm{mg}$ control rats $(P<0.05)$.

** Significantly different from $0.4 \mathrm{mg}$ control rats $(P<0.05)$.

$\dagger$ These rats received thyroxine for at least 10 days before insemination.
}

proportion of the early-hyperthyroid, low progesterone treated rats which was devoid of implantation sites resembled that of animals receiving the higher progesterone dose (Table 1).

Observations were conducted to determine whether the thyroxine injections in the early-hyperthyroid rats produced a change in the number of ovulations and in this way influenced the number of surviving blastocysts. Oviducts of early hyperthyroid and control rats which were flushed with physiological saline on Day 2 of pregnancy yielded almost identical numbers of ova $(12.2$ and $11.8 \mathrm{ova} / \mathrm{rat}$, respectively). This is not in agreement with work of Wilson \& Ghai (1962) who reported that thyroxine treatment decreased the number of ova released in immature mice. 


\section{Hypothyroidism}

Table I summarizes the results obtained with thyroidectomized and control rats maintained on two levels of progesterone. The mean number of sites/rat is about equal in control and thyroidectomized rats receiving $2.0 \mathrm{mg}$ progesterone/day. The thyroidectomized rats receiving $0.3 \mathrm{mg}$ progesterone daily showed fewer sites per rat than the $0.3 \mathrm{mg}$ controls, but this difference was not statistically significant. When the dose of progesterone was lowered from 2.0 to $0.3 \mathrm{mg}$ daily in the control animals there was significant reduction in the number of implantation sites present at autopsy. Also, the proportion of animals without implantation sites increased when the progesterone dosage was decreased.

\section{DISCUSSION}

In the present investigations ovulation was not influenced by the thyroxine injections; hence the increased number of implantation sites in the low progesterone, early-hyperthyroid rats is apparently the result of a well established hyperthyroid condition exerting an effect upon the blastocyst or the uterus. As was the case with hyperthyroid rats, the thyroidectomized and control rats maintained on $2 \mathrm{mg}$ progesterone/day did not differ in the number of implantation sites present at autopsy. Although not statistically significant, the results with low progesterone doses may indicate a tendency for the hypothyroid condition to have an opposite effect to that of the hyperthyroid condition upon blastocyst survival

The results in the present investigation may indicate that alteration of the thyroid activity produces one or a combination of the following - changes in the progesterone requirements for blastocyst survival, alterations in progesterone metabolism, alterations in the uterine or blastocyst sensitivity to progesterone. Nutting \& Meyer (1964) reported that, in rats, the optimum amount of oestrone required for inducing implantation at the normal time appears to be between 0.3 and $1 \mu \mathrm{g}$ daily. The dosage of $1 \mu \mathrm{g}$ daily administered in the present study conforms with this finding. Changes in the uterine sensitivity to oestrogen during alterations of thyroid activity have been reported by Liu (1963), Van Horn (1933) and Langham \& Gustavson (1947). The present experiments were not designed to test for an altered sensitivity to oestrogen. However, had such a change occurred, there would have been a difference between the numbers of implantation sites per rat in the $2 \mathrm{mg}$ control groups and in the experimental groups of both or either of the hyperthyroid or hypothyroid rats; yet all these groups showed about equal numbers of implantation sites.

Further experiments are in progress to investigate the influence of altered thyroid activity and low progesterone levels upon uterine metabolism and upon the metabolism of progesterone. Findings from such experiments should be of value in clarifying the role of the thyroid in reproductive physiology.

\section{ACKNOWLEDGMENTS}

This work was supported by Grant No. HD 01076 from National Institute of Child Health and Human Development. We are also grateful to E. B. Beatty for information about numbers of ova in hyperthyroid and control rats. 


\section{REFERENCES}

Canivenc, R. \& Laffarque, M. (1956) Survie prolongée d'œufs fécondés non-implantés, dans l'utérus de rattes castrées et injectées de progestérone. C. r. hebd. Séanc. Acad. Sci., Paris, 242, 2857.

Cochrane, R. L. \& Meyer, R. K. (1957) Delayed nidation in the rat induced by progesterone. Proc. Soc. exp. Biol. Med. 96, 155.

Desaive, P. (1948) Contribution a l'étude du mécanisme de l'évolution et de l'involution folliculaires dans l'ovaire de lapine adulte (Deuxième Partie). Archs Biol., Paris, 59, 31.

Hoar, R. M., GoY, R. W. \& Young, W. C. (1951) Loci of action of the thyroid hormone on reproduction in the female guinea pig. Endocrinology, 60, 337.

JANES, R. G. \& BRADBURY, J. T. (1952) Ovarian retention cysts in hypothyroid rats treated with diethylstilbestrol. Proc. Soc. exp. Biol. Med. 79, 187.

Johnson, T. N. \& MeItes, J. (1950) Effects of hypo- and hyperthyroidism in rats and mice on ovarian response to equine gonadotrophin. Proc. Soc. exp. Biol. Med. 75, 155.

KRoHN, P. L. (1951) The effects of thyroidectomy on reproduction in the female rabbit. 7. Endocr. 7, 307.

Langham, W. \& Gustavson, R. G. (1947) Effect of level of thyroid activity on response of ovariectomized rats to estrone. Am. F. Physiol. 150, 760 .

Lrv, F. T. Y. (1963) Effect of thyroparathyroidectomy on uterine sensitivity to estrogen in ovariectomized rats. Am. F. Physiol. 205, 457.

MAYER, G. (1963) The experimental control of ovum implantation. In: Techniques in Endocrine Research. Eds. P. Eckstein and F. Knowles. Academic Press, London.

Meyer, R. K. \& Nutting, E. F. (1964) Effect of combination of progesterone and oestrone on the delay of nidation, implantation and foetal survival in ovariectomized rats. F. Endocr. 29, 243.

Nutting, E. F. \& Meyer, R. K. (1963) Implantation delay, nidation, and embryonal survival in rats treated with ovarian hormones. In: Delayed Implantation. Ed. A. G. Enders. University of Chicago Press, Chicago.

Nutting, E. F. \& Meyer, R. K. (1964) Effect of oestrone on the delay of nidation, implantation and foetal survival in ovariectomized rats. $\mathcal{F}$. Endocr. 29, 235.

Peterson, R. R., Webster, R. C., Rayner, B. \& Young, W. C. (1952) The thyroid and reproductive performance in the adult female guinea pig. Endocrinology, 51, 504.

VAN HoRN, W. M. (1933) The relation of the thyroid to the hypophysis and ovary. Endocrinology, 17, 152.

Williams, R. H., Weinglass, A. R., Bissel, G. W. \& Peters, J. B. (1944) Anatomical effects of thiouracil. Endocrinology, 34, 317.

Wilson, E. B. \& GhaI, C. K. (1962) The influence of propylthiouracil and thyroxine on superovulation in immature mice. $\mathcal{F}$. Endocr. 24, 431. 